\title{
The fester locus in Botryllus schlosseri experiences selection
}

\author{
Marie L Nydam ${ }^{1 *}$ and Anthony W De Tomaso ${ }^{2}$
}

\begin{abstract}
Background: Allorecognition, the ability of an organism to distinguish self from non-self, occurs throughout the entire tree of life. Despite the prevalence and importance of allorecognition systems, the genetic basis of allorecognition has rarely been characterized outside the well-known MHC (Major Histocompatibility Complex) in vertebrates and SI (Self-Incompatibility) in plants. Where loci have been identified, their evolutionary history is an open question. We have previously identified the genes involved in self/non-self recognition in the colonial ascidian Botryllus schlosseri, and we can now begin to investigate their evolution. In B. schlosseri, colonies sharing 1 or more alleles of a gene called FuHC (Fusion Histocompatibility) will fuse. Protein products of a locus called fester, located $\sim 300 \mathrm{~kb}$ from FuHC, have been shown to play multiple roles in the histocompatibility reaction, as activating and/or inhibitory receptors. We test whether the proteins encoded by this locus are evolving neutrally or are experiencing balancing, directional, or purifying selection.

Results: Nearly all of the variation in the fester locus resides within populations. The 13 housekeeping genes (12 nuclear genes and mitochondrial cytochrome oxidase I) have substantially more structure among populations within groups and among groups than fester. All polymorphism statistics (Tajima's D, Fu and Li's D* and F*) are significantly negative for the East Coast A-type alleles, and Fu and Li's $F^{*}$ statistic is significantly negative for the West Coast A-type alleles. These results are likely due to selection rather than demography, given that 10 of the housekeeping loci have no populations with significant values for any of the polymorphism statistics. The majority of codons in the fester proteins have $\omega$ values $<1$, but 15-27 codons have $>95 \%$ posterior probability of $\omega$ values $>1$.

Conclusion: Fester proteins are evolving non-neutrally. The polymorphism statistics are consistent with either purifying selection or directional selection. The $\omega$ statistics show that the majority of the protein is experiencing purifying selection $(\omega<1)$, but that $15-27$ codons are undergoing either balancing or directional selection: $\omega>1$ is compatible with either scenario. The distribution of variation within and among populations points towards balancing selection and away from directional selection. While these data do not provide unambiguous support for a specific type of selection, they contribute to our evolutionary understanding of a critical biological process by determining the forces that affect loci involved in allorecognition.
\end{abstract}

Keywords: Allorecognition, Selection, Fester, Botryllus schlosseri

\footnotetext{
* Correspondence: marie.nydam@centre.edu

1 Division of Science and Mathematics, Centre College, 600 W. Walnut Street, Danville, KY 40422, USA

Full list of author information is available at the end of the article
} 


\section{Background}

Allorecognition is the ability of an organism to differentiate self or close relatives from unrelated individuals. Examples of allorecognition include the selfincompatibility (SI) systems in plants, vertebrate immune response to foreign antigens mediated by MHC loci, and fusion/rejection, where two genetically independent individuals physically join to become a single individual or reject each other. Effective allorecognition systems are critical to the survival of organisms: the SI loci prevent inbreeding depression, T-lymphocytes educated by $\mathrm{MHC}$ molecules protect vertebrates against pathogens, and fusing to a closely related individual can provide competitive and reproductive advantages where space is limited and reproductive output is based on the size of the organism [1]. Allorecognition occurs across the tree of life [1], in anemones [2], angiosperms [3], ascidians [4-6], bacteria [7], bryozoans [8], cellular slime molds [9], corals [10], fungi [11], hydroids [12], gymnosperms [13,14], plasmodial slime molds [15], red algae [16], sponges [17], and vertebrates [18].

Despite the prevalence and importance of allorecognition systems, the genetic basis of allorecognition has rarely been characterized outside the well-known MHC in vertebrates and SI in plants. The genes responsible for allorecognition have recently been identified in a handful of systems: a bacterium [7], a colonial ascidian [19], a cellular slime mold [20], fungi [11], a hydroid [21], and a solitary ascidian [6]. Only in the ascidian systems have we identified putative receptor-ligand pairs [22]; ligands bind to receptors on the cell surface.

In the colonial ascidian Botryllus schlosseri, allorecognition occurs when terminal projections of an extracorporeal vasculature, called ampullae, come into contact between juxtaposed colonies. If colonies are compatible, the ampullae will fuse, forming a parabiosis between the two colonies. If they are incompatible, the ampullae will undergo a rejection reaction which prevents vascular fusion. The polymorphisms of a gene called FuHC (Fusion/HistoCompatibility) determine 100\% of histocompatibility outcomes between interacting colonies: fusion occurs if the colonies share 1 or more FuHC alleles [19, Nydam et al., unpublished data].

Another polymorphic locus, called fester, is encoded $\sim 300 \mathrm{~Kb}$ from the FuHC; FuHC and fester are tightly linked [22]. Fester appears to encode a cell-surface receptor involved in multiple aspects of histocompatibility in B. schlosseri. From a genetic standpoint, fester displays a characteristic reminiscent of all immune genes diversity.

Fester achieves diversity through several mechanisms. First, the locus is highly polymorphic, and encodes over 60 protein alleles, although these polymorphisms do not contribute to histocompatibility outcomes [22]. Because fester is likely a receptor of the ligand FuHC [22], these polymorphisms can tell us how fester and FuHC interact at the molecular level to determine histocompatibility outcomes. Specifically, regions of high polymorphism in fester could indicate domains that bind with $\mathrm{FuHC}$, and vice versa.

Second, a preliminary phylogenetic analysis of fester coding sequences split them into 4 groups: A, B1, B2, and $C$ [22]. The A haplotype has a single copy of fester, while the B haplotype encodes 2 linked duplicates (B1 and $\mathrm{B} 2$ ). At present, the composition of the $\mathrm{C}$ haplotype is unknown. There are no other fester genes anywhere else, based on our crossing data [22]. We will use the term haplotype to refer to the $\mathrm{A}, \mathrm{B} 1 / \mathrm{B} 2$ and $\mathrm{C}$ haplotypes in this article. Figure 1 provides a visual representation of these haplotypes.

Finally, the fester locus is diversified in each colony via alternative splicing [22]. The fester locus is encoded in 11 exons, 6 of which can be alternatively spliced in all combinations, making a total of 64 potential splice variants. Each colony examined expresses a full-length fester mRNA, 3 common alternative splice variants, as well as a unique repertoire of 8-24 different alternative splice variants; Exons 6 and 7 are very commonly spliced out [22]. Exons 1-7 correspond to the extracellular domain of the protein, and Exons 8-10 to 3 predicted transmembrane domains [22]. In the present data set, the PCR primers always amplified all 11 exons. However, the full-length cDNA was rarely incorporated into the bacterial vector; the longest amplicons recovered from the cloning process were almost always missing Exons 6 and 7.

Functionally, 2 experiments support a role of the fester protein in histocompatibility. A monoclonal antibody $(\mathrm{mAB})$ experiment, whereby the histocompatibility reaction is interrupted by a $\mathrm{mAB}$ that binds to and activates the fester protein, resulted in a rejection being converted

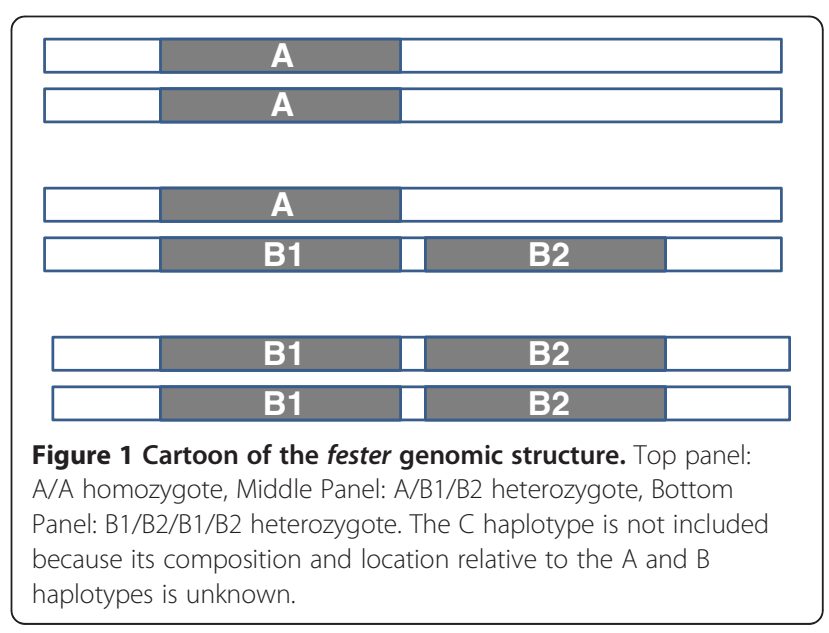


to a fusion. This conversion only occurred in pairings involving fester genotypes that expressed the fester allele that binds to the mAB [22]. Fester could therefore be a receptor which binds to FuHC, blocking an ongoing rejection reaction and initiating the fusion event [22]. In contrast, a siRNA experiment, in which the expression of the fester protein is blocked, turned both fusion and rejection phenotypes into no response phenotypes, and ampullae were inert [22]. This result suggests that fester also plays a role in initiating the rejection reaction. Given this dual role, if fester is not expressed, no histocompatibility reaction occurs: a rejection reaction cannot occur because it is not initiated, and a fusion cannot occur because no receptors can detect the FuHC.

We know very little about the evolution of allorecognition loci outside MHC and SI, but we have several reasons to hypothesize that loci like fester may be evolving non-neutrally. First, abundant evidence exists for selection acting on both ligands and receptors directly involved in MHC (reviewed in [23,24]) and SI (reviewed in [25]). Second, fester is highly polymorphic [22]; a neutral model of evolution is unlikely to explain allelic diversity found in fester and other allorecognition loci [26].

We will use three approaches to infer whether fester is experiencing selection or genetic drift: distribution of polymorphism within and among populations (AMOVA and $\mathrm{F}_{\mathrm{ST}}$ calculations), polymorphism statistics, and $\omega$ statistics. AMOVA and $\mathrm{F}_{\mathrm{ST}}$ values for fester alleles will be compared to housekeeping genes. If the fester alleles are outliers with respect to the housekeeping loci, this will be taken as evidence for selection. Polymorphism statistics $\left(\mathrm{D}, \mathrm{D}^{*}, \mathrm{~F}^{*}\right)$ look for evidence of selection using a genealogical framework; values significantly different from zero are evidence for selection. The $\omega$ statistic calculates the posterior probability that particular codons are experiencing selection.

If selection is acting on fester, we will examine the support for three types of selection: balancing, directional, and purifying. Using AMOVA and $\mathrm{F}_{\mathrm{ST}}$ statistics, a low amount of polymorphism within populations compared to housekeeping genes is consistent with directional selection; the opposite pattern is consistent with balancing selection [27]. Polymorphism statistics (D, $\left.\mathrm{D}^{*}, \mathrm{~F}^{*}\right)$ are less than zero when purifying or directional selection is operating, and greater than zero when balancing selection is operating $[28,29]$. An $\omega$ value greater than 1 supports directional or balancing selection, and less than 1 supports purifying selection [30]. In the few cases where allorecognition loci have been studied in an evolutionary framework, balancing selection is more prevalent than purifying or directional selection [25]. If we find that fester alleles evolve under selection, we therefore expect to find evidence for balancing selection.

\section{Results}

\section{Sampling}

Colonies were collected from floating docks in each of 6 populations in 2009 and 2010: Falmouth, MA, Quissett, MA, Sandwich, MA, Monterey, CA, Santa Barbara, CA and Seattle, WA. Falmouth, MA and Quissett, MA are 3 miles apart, on Vineyard Sound and Buzzards Bay, respectively. Sandwich, MA is 25 miles from the Falmouth/Quissett area, on Cape Cod Bay. Santa Barbara, CA is 237 miles south of Monterey, CA and 1,113 miles south of Seattle, WA.

\section{Relationships among fester haplotypes}

We constructed phylogenetic trees to evaluate the evolutionary relationships between the fester haplotypes. ML and Bayesian methods show the A-type alleles, the B1/ B2-type alleles and the C-type alleles to be monophyletic groups (Figure 2, Additional file 1). In all analyses, the 2 B2-type alleles group together, but B1 is paraphyletic with respect to $\mathrm{B} 2$. The $\mathrm{B} 2$ clade has strong support (Bayesian posterior probability $=1.0, \mathrm{ML}$ bootstrap value $=0.93)$.

\section{Comparison of variation among fester allele types}

We compared variation and diversity among fester allele types to inform our understanding of the evolution of these allele types. Significantly more variation exists in the $A$ clade than in either $\mathrm{B} 1 / \mathrm{B} 2$ or $\mathrm{C} . \mathrm{D}_{\mathrm{xy}} / \mathrm{D}_{\mathrm{a}}$ values quantify this disparity: A clade vs. B1/B2 clade $=0.061$ / 0.050 , A clade vs. $\mathrm{C}$ clade $=0.061 / 0.051, \mathrm{~B} 1 / \mathrm{B} 2$ clade vs. $\mathrm{C}$ clade $=0.047 / 0.032$. Because $\mathrm{D}_{\mathrm{a}}$ corrects for withinallele type variation, the higher variation in the A-type alleles is not an artifact of more colonies having A-type alleles than B1/B2 or C-type alleles.

When A-type alleles are compared between East Coast and West Coast, several measures of diversity $(\pi$ based on all sites, $\pi$ based on synonymous sites, Watterson's $\Theta$, and haplotype diversity) are larger for the East Coast group than for the West Coast group (Table 1). We sampled 22 colonies with A-type alleles from the East Coast, and 18 colonies with A-type alleles from the West Coast.

\section{Recombination}

All populations (A-type East and West Coasts, B1-type and C-type East Coast) experience intragenic recombination. 2 and 1 minimum number of recombination events $\left(R_{m}\right)$ are found in the A-type East and West Coast groups, respectively. For A-type East Coast, recombination is detected between sites 279,300 (in Exon 3) and 338,731 (between Exons 4 and 8). For A-type West Coast, recombination is detected between sites 447,701 (between Exons 4 and 8). Significant negative correlations between physical distance and all 3 


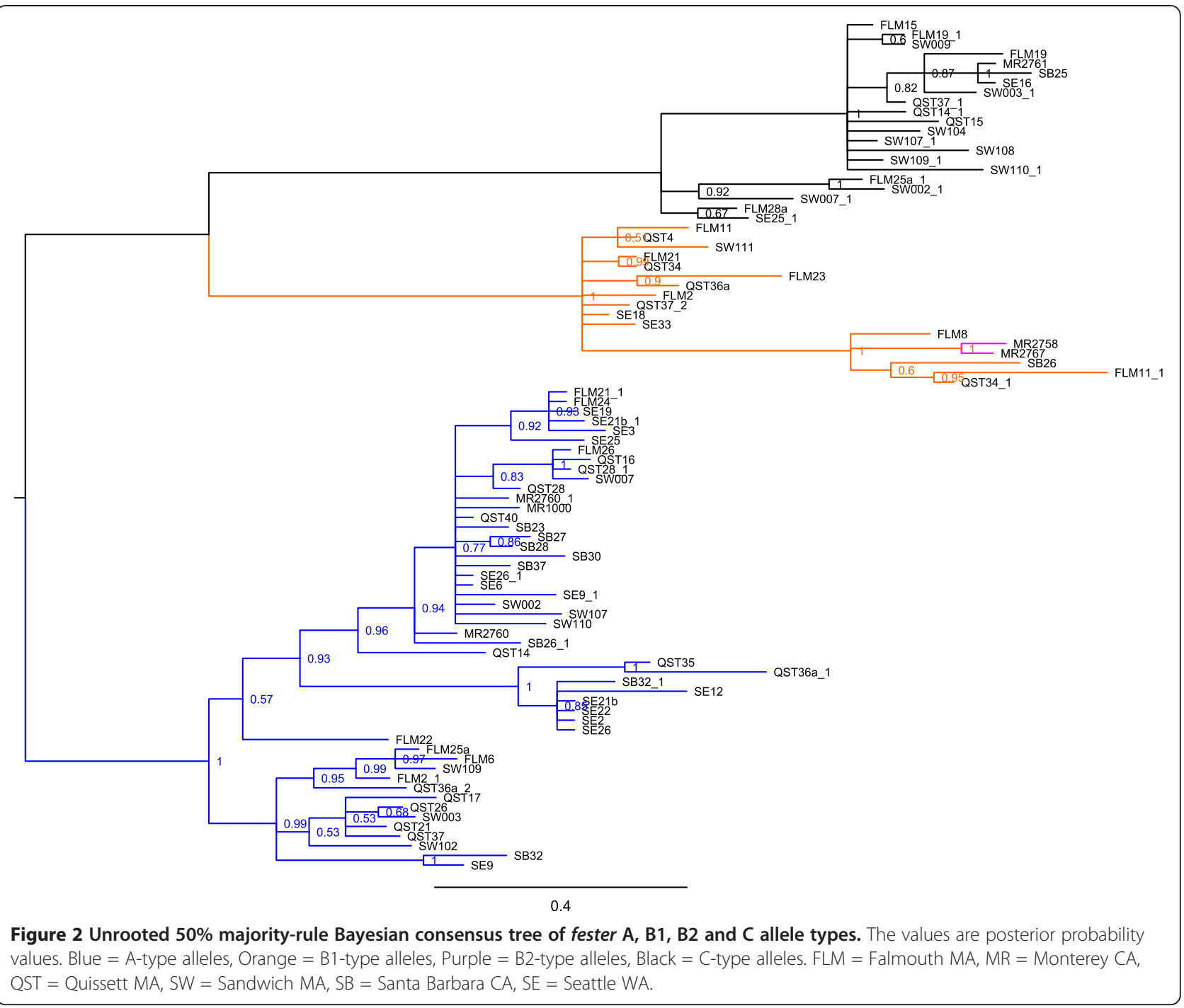

measures of LD for East Coast A-type alleles, and for 1 measure of LD for West Coast A-type alleles $(\mathrm{p}=0.001$ in all significant negative correlations). The East Coast B1-type and C-type alleles have 0 minimum recombination events, but significant negative correlations between physical distance and all 3 measures of LD are found in both groups ( $\mathrm{p}=0.001$ in all significant negative correlations).

\section{Selection inference: distribution of polymorphism within and among populations \\ Fester}

Analyzing the distribution of fester polymorphism within and among populations and comparing these distributions to housekeeping genes allows us to make inferences about whether selection is occurring at fester alleles. AMOVA, fixation indices $\left(F_{\mathrm{ct}}, \mathrm{F}_{\mathrm{sc}}\right.$ and $\left.\mathrm{F}_{\mathrm{st}}\right)$, and pairwise $F_{\text {st }}$ values for all allele types are shown in Additional file 2. The two groups are all East Coast populations taken together, and all West Coast populations taken together. For the A-type alleles, $96 \%$ of the variation is found within populations and there is no significant differentiation among groups, among populations within groups, or among populations among groups. Only $1 / 15$ pairwise $F_{\text {st }}$ values is significant (Quissett, MA vs. Santa Barbara, CA). Qualitative results are identical for the B1-type and C-type alleles: $100 \%$ of the variation is found within (as opposed to among) populations, neither global $F_{\text {st }}$ nor pairwise $F_{\text {st }}$ values are significant. Clearly, fester variation is found exclusively within populations.

The allele types show some geographic signature. The A-type alleles, by far the most common (present in $71 \%$ of colonies sequenced), are found in similar numbers in East Coast and West Coast populations (27 East Coast alleles, 24 West Coast alleles), but the B1-type and Ctype allele types are rarely found on the West Coast (2/ 13 B1-type alleles and 4/21 C-type alleles). Only 2 B2- 
Table $1 \pi, \theta-w$, \# haplotypes, haplotype diversity

\begin{tabular}{|c|c|c|c|c|c|c|}
\hline \multicolumn{7}{|c|}{ Fester A-type alleles } \\
\hline Population & $\pi$ (All Sites) & $\pi$ (Synonymous) & $\pi$ (Nonsynonymous) & Ө-w (per site) & \# Haplotypes & Haplotype diversity \\
\hline East Coast & 0.020 & 0.020 & 0.010 & 0.030 & 17 & 0.96 \\
\hline West Coast & 0.010 & 0.010 & 0.010 & 0.010 & 13 & 0.90 \\
\hline \multicolumn{7}{|c|}{ Fester B1-type alleles } \\
\hline Population & $\pi$ (All Sites) & $\pi$ (Synonymous) & $\pi$ (Nonsynonymous) & Ө-w (per site) & \# Haplotypes & Haplotype diversity \\
\hline East Coast & 0.010 & 0.030 & 0.010 & 0.010 & 8 & 0.95 \\
\hline \multicolumn{7}{|c|}{ Fester C-type alleles } \\
\hline Population & $\pi$ (All Sites) & $\pi$ (Synonymous) & $\pi$ (Nonsynonymous) & Ө-w (per site) & \# Haplotypes & Haplotype diversity \\
\hline East Coast & 0.010 & 0.030 & 0.010 & 0.020 & 13 & 0.93 \\
\hline \multicolumn{7}{|l|}{ 40S_3A } \\
\hline Population & $\pi$ (All Sites) & $\pi$ (Synonymous) & $\pi$ (Nonsynonymous) & $\Theta-w$ (per site) & \# Haplotypes & Haplotype diversity \\
\hline Falmouth, MA & 0.001 & 0.014 & 0.000 & 0.002 & 6 & 0.533 \\
\hline Quissett, MA & 0.001 & 0.004 & 0.000 & 0.001 & 3 & 0.600 \\
\hline Sandwich, MA & 0.002 & 0.011 & 0.000 & 0.002 & 3 & 0.833 \\
\hline Monterey, CA & NA & NA & NA & NA & 1 & 0.000 \\
\hline Santa Barbara, CA & 0.006 & 0.025 & 0.000 & 0.006 & 2 & 0.500 \\
\hline Seattle, WA & 0.009 & 0.040 & 0.000 & 0.007 & 3 & 0.800 \\
\hline All populations & 0.003 & 0.014 & 0.000 & 0.005 & 9 & 0.658 \\
\hline
\end{tabular}

\begin{tabular}{|c|c|c|c|c|c|c|}
\hline \multicolumn{7}{|l|}{ 60S_L6 } \\
\hline Population & $\pi$ (All Sites) & $\pi$ (Synonymous) & $\pi$ (Nonsynonymous) & $\Theta-w$ (per site) & \# Haplotypes & Haplotype diversity \\
\hline Falmouth, MA & 0.002 & 0.006 & 0.001 & 0.003 & 5 & 0.455 \\
\hline Quissett, MA & 0.001 & 0.003 & 0.000 & 0.002 & 5 & 0.433 \\
\hline Sandwich, MA & 0.002 & 0.005 & 0.000 & 0.002 & 5 & 0.547 \\
\hline Monterey, CA & 0.008 & 0.015 & 0.006 & 0.008 & 3 & 0.511 \\
\hline Santa Barbara, CA & 0.002 & 0.004 & 0.002 & 0.004 & 8 & 0.699 \\
\hline Seattle, WA & 0.002 & 0.007 & 0.001 & 0.003 & 8 & 0.678 \\
\hline All populations & 0.003 & 0.008 & 0.002 & 0.007 & 18 & 0.711 \\
\hline \multicolumn{7}{|l|}{ 60S_L8 } \\
\hline Population & $\pi$ (All Sites) & $\pi$ (Synonymous) & $\pi$ (Nonsynonymous) & $\Theta-w$ (per site) & \# Haplotypes & Haplotype diversity \\
\hline Falmouth, MA & 0.001 & 0.003 & 0.001 & 0.002 & 5 & 0.524 \\
\hline Quissett, MA & 0.002 & 0.004 & 0.001 & 0.002 & 5 & 0.599 \\
\hline Sandwich, MA & 0.002 & 0.003 & 0.001 & 0.002 & 3 & 0.833 \\
\hline Monterey, CA & 0.001 & 0.003 & 0.000 & 0.001 & 2 & 0.500 \\
\hline Santa Barbara, CA & NA & NA & NA & NA & NA & NA \\
\hline Seattle, WA & 0.001 & 0.002 & 0.001 & 0.001 & 3 & 0.506 \\
\hline All populations & 0.002 & 0.003 & 0.001 & 0.001 & 5 & 0.593 \\
\hline \multicolumn{7}{|l|}{ 60S_L10 } \\
\hline Population & $\pi$ (All Sites) & $\pi$ (Synonymous) & $\pi$ (Nonsynonymous) & $\Theta-w$ (per site) & \# Haplotypes & Haplotype diversity \\
\hline Falmouth, MA & 0.005 & 0.020 & 0.000 & 0.007 & 7 & 0.393 \\
\hline Quissett, MA & 0.007 & 0.032 & 0.000 & 0.007 & 6 & 0.693 \\
\hline Sandwich, MA & 0.003 & 0.014 & 0.000 & 0.004 & 2 & 0.333 \\
\hline Monterey, CA & 0.009 & 0.039 & 0.000 & 0.009 & 6 & 0.929 \\
\hline Santa Barbara, CA & 0.010 & 0.041 & 0.000 & 0.009 & 7 & 0.911 \\
\hline Seattle, WA & 0.008 & 0.035 & 0.000 & 0.005 & 10 & 0.776 \\
\hline All populations & 0.008 & 0.036 & 0.000 & 0.007 & 18 & 0.672 \\
\hline
\end{tabular}


Table $1 \pi, \theta-w$, \# haplotypes, haplotype diversity (Continued)

\begin{tabular}{|c|c|c|c|c|c|c|}
\hline \multicolumn{7}{|l|}{ 60S_L13 } \\
\hline Population & $\pi$ (All Sites) & $\pi$ (Synonymous) & $\pi$ (Nonsynonymous) & Ө-w (per site) & \# Haplotypes & Haplotype diversity \\
\hline Falmouth, MA & 0.007 & 0.018 & 0.004 & 0.005 & 13 & 0.833 \\
\hline Quissett, MA & 0.008 & 0.019 & 0.004 & 0.006 & 7 & 0.655 \\
\hline Sandwich, MA & 0.006 & 0.016 & 0.004 & 0.007 & 2 & 0.500 \\
\hline Monterey, CA & 0.003 & 0.009 & 0.001 & 0.002 & 3 & 0.644 \\
\hline Santa Barbara, CA & 0.007 & 0.021 & 0.003 & 0.005 & 4 & 0.714 \\
\hline Seattle, WA & 0.008 & 0.026 & 0.003 & 0.006 & 16 & 0.903 \\
\hline All populations & 0.010 & 0.028 & 0.004 & 0.006 & 19 & 0.833 \\
\hline \multicolumn{7}{|l|}{$71 \mathrm{kda}$} \\
\hline Population & $\pi$ (All Sites) & $\pi$ (Synonymous) & $\pi$ (Nonsynonymous) & Ө-w (per site) & \# Haplotypes & Haplotype diversity \\
\hline Falmouth, MA & 0.004 & 0.014 & 0.000 & 0.005 & 10 & 0.804 \\
\hline Quissett, MA & 0.004 & 0.014 & 0.001 & 0.005 & 9 & 0.735 \\
\hline Sandwich, MA & 0.006 & 0.023 & 0.001 & 0.006 & 13 & 0.896 \\
\hline Monterey, CA & 0.009 & 0.037 & 0.000 & 0.007 & 5 & 0.867 \\
\hline Santa Barbara, CA & 0.008 & 0.032 & 0.000 & 0.006 & 19 & 0.943 \\
\hline Seattle, WA & 0.004 & 0.014 & 0.001 & 0.004 & 7 & 0.909 \\
\hline All populations & 0.008 & 0.029 & 0.001 & 0.007 & 47 & 0.906 \\
\hline \multicolumn{7}{|l|}{ actin } \\
\hline Population & $\pi$ (All Sites) & $\pi$ (Synonymous) & $\pi$ (Nonsynonymous) & Ө-w (per site) & \# Haplotypes & Haplotype diversity \\
\hline Falmouth, MA & 0.004 & 0.017 & 0.000 & 0.005 & 12 & 0.879 \\
\hline Quissett, MA & 0.006 & 0.025 & 0.000 & 0.005 & 14 & 0.931 \\
\hline Sandwich, MA & 0.005 & 0.021 & 0.000 & 0.006 & 12 & 0.918 \\
\hline Monterey, CA & 0.004 & 0.015 & 0.000 & 0.004 & 4 & 0.652 \\
\hline Santa Barbara, CA & 0.005 & 0.022 & 0.000 & 0.005 & 18 & 0.954 \\
\hline Seattle, WA & 0.005 & 0.020 & 0.000 & 0.004 & 6 & 0.818 \\
\hline All populations & 0.005 & 0.022 & 0.000 & 0.007 & 44 & 0.924 \\
\hline \multicolumn{7}{|c|}{ ADP/ATP translocase } \\
\hline Population & $\pi$ (All Sites) & $\pi$ (Synonymous) & $\pi$ (Nonsynonymous) & Ө-w (per site) & \# Haplotypes & Haplotype diversity \\
\hline Falmouth, MA & 0.008 & 0.029 & 0.001 & 0.007 & 13 & 0.863 \\
\hline Quissett, MA & 0.014 & 0.052 & 0.002 & 0.014 & 3 & 0.833 \\
\hline Sandwich, MA & 0.005 & 0.020 & 0.000 & 0.005 & 3 & 0.833 \\
\hline Monterey, CA & 0.020 & 0.082 & 0.000 & 0.020 & 2 & 1.000 \\
\hline Santa Barbara, CA & NA & NA & NA & NA & NA & NA \\
\hline Seattle, WA & 0.012 & 0.046 & 0.001 & 0.012 & 4 & 1.000 \\
\hline All populations & 0.009 & 0.034 & 0.001 & 0.007 & 18 & 0.915 \\
\hline \multicolumn{7}{|l|}{ Hsp90 } \\
\hline Population & $\pi$ (All Sites) & $\pi$ (Synonymous) & $\pi$ (Nonsynonymous) & Ө-w (per site) & \# Haplotypes & Haplotype diversity \\
\hline Falmouth, MA & 0.015 & 0.065 & 0.001 & 0.020 & 13 & 0.788 \\
\hline Quissett, MA & 0.010 & 0.044 & 0.001 & 0.016 & 13 & 0.812 \\
\hline Sandwich, MA & 0.018 & 0.079 & 0.001 & 0.012 & 7 & 0.911 \\
\hline Monterey, CA & 0.002 & 0.008 & 0.000 & 0.002 & 8 & 0.909 \\
\hline Santa Barbara, CA & 0.002 & 0.008 & 0.000 & 0.002 & 9 & 0.815 \\
\hline Seattle, WA & 0.014 & 0.063 & 0.001 & 0.013 & 3 & 0.464 \\
\hline All populations & 0.010 & 0.045 & 0.001 & 0.014 & 23 & 0.685 \\
\hline
\end{tabular}


Table $1 \pi, \boldsymbol{\theta}-\mathbf{w}$, \# haplotypes, haplotype diversity (Continued)

\begin{tabular}{|c|c|c|c|c|c|c|}
\hline \multicolumn{7}{|l|}{ ma2_actin } \\
\hline Population & $\pi$ (All Sites) & $\pi$ (Synonymous) & $\pi$ (Nonsynonymous) & $\Theta-w$ (per site) & \# Haplotypes & Haplotype diversity \\
\hline Falmouth, MA & 0.003 & 0.013 & 0.000 & 0.004 & 9 & 0.831 \\
\hline Quissett, MA & 0.004 & 0.016 & 0.000 & 0.004 & 8 & 0.857 \\
\hline Sandwich, MA & 0.003 & 0.011 & 0.000 & 0.004 & 7 & 0.768 \\
\hline Monterey, CA & 0.004 & 0.017 & 0.000 & 0.006 & 3 & 0.385 \\
\hline Santa Barbara, CA & 0.004 & 0.016 & 0.000 & 0.004 & 4 & 0.458 \\
\hline Seattle, WA & 0.003 & 0.016 & 0.000 & 0.003 & 4 & 0.542 \\
\hline All populations & 0.005 & 0.019 & 0.000 & 0.006 & 13 & 0.777 \\
\hline \multicolumn{7}{|l|}{ mtCOI } \\
\hline Population & $\pi$ (All Sites) & $\pi$ (Synonymous) & $\pi$ (Nonsynonymous) & $\Theta-w$ (per site) & \# Haplotypes & Haplotype diversity \\
\hline Falmouth, MA & 0.009 & 0.031 & 0.002 & 0.016 & 4 & 0.491 \\
\hline Quissett, MA & 0.007 & 0.035 & 0.002 & 0.010 & 5 & 0.405 \\
\hline Sandwich, MA & 0.026 & 0.094 & 0.004 & 0.158 & 3 & 0.833 \\
\hline Monterey, CA & 0.002 & 0.007 & 0.000 & 0.003 & 2 & 0.400 \\
\hline Santa Barbara, CA & 0.004 & 0.015 & 0.002 & 0.010 & 6 & 0.468 \\
\hline Seattle, WA & 0.025 & 0.105 & 0.002 & 0.018 & 4 & 0.711 \\
\hline All populations & 0.021 & 0.093 & 0.002 & 0.013 & 11 & 0.725 \\
\hline \multicolumn{7}{|l|}{ vasa } \\
\hline Population & $\pi$ (All Sites) & $\pi$ (Synonymous) & $\pi$ (Nonsynonymous) & $\Theta-w$ (per site) & \# Haplotypes & Haplotype diversity \\
\hline Falmouth, MA & 0.004 & 0.011 & 0.001 & 0.004 & 6 & 0.733 \\
\hline Quissett, MA & 0.020 & 0.080 & 0.002 & 0.020 & 7 & 0.800 \\
\hline Sandwich, MA & 0.023 & 0.095 & 0.000 & 0.020 & 10 & 0.970 \\
\hline Monterey, CA & 0.012 & 0.047 & 0.001 & 0.010 & 5 & 0.857 \\
\hline Santa Barbara, CA & 0.025 & 0.097 & 0.003 & 0.020 & 8 & 0.859 \\
\hline Seattle, WA & 0.013 & 0.055 & 0.000 & 0.011 & 5 & 0.861 \\
\hline All populations & 0.022 & 0.088 & 0.002 & 0.026 & 23 & 0.750 \\
\hline \multicolumn{7}{|l|}{ Vigilin } \\
\hline Population & $\pi$ (All Sites) & $\pi$ (Synonymous) & $\pi$ (Nonsynonymous) & $\Theta-w$ (per site) & \# Haplotypes & Haplotype diversity \\
\hline Falmouth, MA & 0.011 & 0.037 & 0.004 & 0.017 & 9 & 0.934 \\
\hline Quissett, MA & 0.023 & 0.080 & 0.007 & 0.017 & 15 & 0.980 \\
\hline Sandwich, MA & 0.019 & 0.065 & 0.007 & 0.016 & 11 & 0.958 \\
\hline Monterey, CA & 0.018 & 0.069 & 0.004 & 0.018 & 5 & 0.893 \\
\hline Santa Barbara, CA & 0.018 & 0.070 & 0.004 & 0.016 & 23 & 0.938 \\
\hline Seattle, WA & 0.018 & 0.064 & 0.004 & 0.017 & 5 & 0.822 \\
\hline All populations & 0.024 & 0.088 & 0.006 & 0.016 & 55 & 0.971 \\
\hline
\end{tabular}

type alleles are present in our samples, and although they are both found in the Monterey population, we cannot conclude anything about the geographic structuring of this allele type with so few samples.

\section{Housekeeping genes}

The housekeeping genes are as follows: mitochondrial COI, $40 \mathrm{~S}$ ribosomal protein $3 \mathrm{~A}, 60 \mathrm{~S}$ ribosomal protein L6, 60S ribosomal protein L8, 60S ribosomal protein L10, 60S ribosomal protein L13, adult-type muscle actin
2 , heat shock cognate $71 \mathrm{kda}$ protein, cytoplasmic actin 2, ADP/ATP translocase 3, heat shock protein HSP-90 beta, vasa, and vigilin. The housekeeping genes show a pattern that contrasts with fester. All housekeeping loci have a substantially lower percentage of the variation within populations than fester (Figure 3). All loci have a substantially higher percentage of the variation among groups than fester although $\mathrm{F}_{\mathrm{ct}}$ is not significant for any locus (Additional file 2). All loci have a substantially higher percentage of the variation among populations 


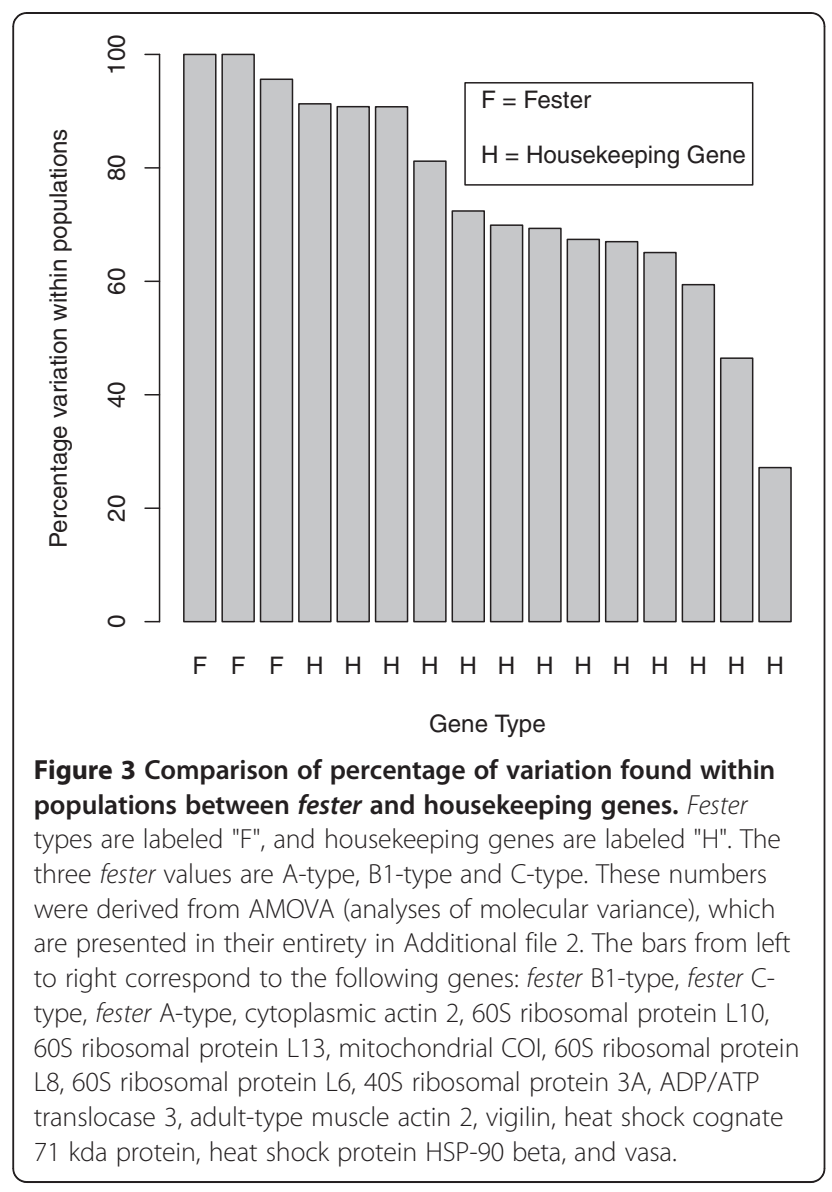

within groups than fester, and $\mathrm{F}_{\mathrm{sc}}$ is significant for all loci but 1 (Additional file 2). Significant differentiation exists among populations among groups: overall $\mathrm{F}_{\text {st }}$ is significant for all loci, and a majority of pairwise $\mathrm{F}_{\mathrm{st}}$ values are significant.

\section{Tests of selection: polymorphism statistics Fester}

Table 1 shows $\theta$ and $\pi$ for each allele type. For the Atype alleles, East Coast has higher levels of polymorphism than West Coast. B1-type and C-type East Coast groups have polymorphism values similar to those of the A-type West Coast group.

Table 2 displays Tajima's D values for A-type East and West Coasts, and B1-type/C-type East Coast. Coalescent simulations given $\theta$ and segregating sites show similar $\mathrm{p}$ values (and always with the same qualitative result), so only results from the simulations given $\theta$ will be shown. A-type: D values are significantly negative for East Coast only. B1-type and C type East Coast D values are also negative, but are not statistically significant.

$\mathrm{Fu}$ and Li's D* and $\mathrm{F}^{*}$ values are presented in Table 2. Coalescent simulations given $\theta$ and segregating sites show similar p-values (and always with the same
Table 2 Tajima's D, Fu and Li's D* and F* statistics for fester A, B1 and C allele types

\begin{tabular}{lccc}
\hline Allele type and Location & $\begin{array}{c}\text { Tajima's } \\
\text { D value }\end{array}$ & $\begin{array}{c}\text { Fu and Li's } \\
\mathbf{D}^{*} \text { value }\end{array}$ & $\begin{array}{c}\text { Fu and Li's } \\
\text { F* value }^{*}\end{array}$ \\
\hline A-type alleles East Coast & $-1.31^{*}$ & $-1.96^{*}$ & $-1.96^{*}$ \\
A-type alleles West Coast & -1.01 & -0.85 & $-0.95^{*}$ \\
B1-type alleles East Coast & -0.99 & -0.27 & -0.52 \\
C-type alleles East Coast & -1.26 & -1.51 & -1.67
\end{tabular}

Asterisks represent $D, D^{*}$ or $F^{*}$ values with associated $p$ values that are less than 0.05 .

qualitative result), so only results from the simulations given $\theta$ will be shown. Both A-type groups have significantly negative $\mathrm{D}^{*}$ values, but only East Coast has significantly negative $F^{*}$ values. Just as in the Tajima's D analyses, B1-type and C-type East Coast D values are negative, but $p$ values from the coalescent simulations are $>0.05$ in all cases.

\section{Housekeeping genes}

Summary statistics, shown in Table 2, have consistently lower values for the housekeeping genes than for fester. Values for Tajima's D, Fu and Li's $\mathrm{D}^{*}$ and $\mathrm{F}^{*}$ can be found in Additional file 3. We see very few significant values for the housekeeping loci. For mtCOI, two populations are significant for all three statistics. For $60 \mathrm{~S}$ ribosomal protein L10, one population is significant for all three statistics. For vasa, one population is significant for one statistic. None of the other housekeeping loci have populations with significant values for any of the three statistics.

We also noted that all $\mathrm{D}, \mathrm{D}^{*}$ and $\mathrm{F}^{*}$ values across populations are negative for fester. For the housekeeping genes, only cytoplasmic actin 2 shows a pattern of consistent negative values across populations for the polymorphism statistics. $40 \mathrm{~S}$ ribosomal protein 3A, 60S ribosomal protein L8, 60S ribosomal protein L10, ADP/ ATP translocase, HSP 90 beta and mtCOI show no trend towards positive or negative values across populations for any of the three statistics. $60 \mathrm{~S}$ ribosomal protein L6 and adult-type muscle actin 2 are negative across populations for Tajima's D, but no pattern is seen in either D* or $\mathrm{F}^{*}$. Heat shock cognate $71 \mathrm{kda}$ protein and vasa have no pattern for Tajima's D, but a majority of populations have positive values for $\mathrm{D}^{*}$ and $\mathrm{F}^{*}$. $60 \mathrm{~S}$ ribosomal protein L13 shows a pattern of positive values across populations for all three statistics.

To further compare housekeeping genes and fester, we calculated mean Tajima's D, Fu and Li's D*, and Fu and Li's $F^{*}$ values (across all six populations) for housekeeping genes. We then compared these values to $\mathrm{D}, \mathrm{D}^{*}$ and $\mathrm{F}^{*}$ for fester A-type East Coast, A-type West Coast, B1type East Coast, and C-type West Coast (Figures 4, 5, 6). For all of the statistics, the fester values and the 


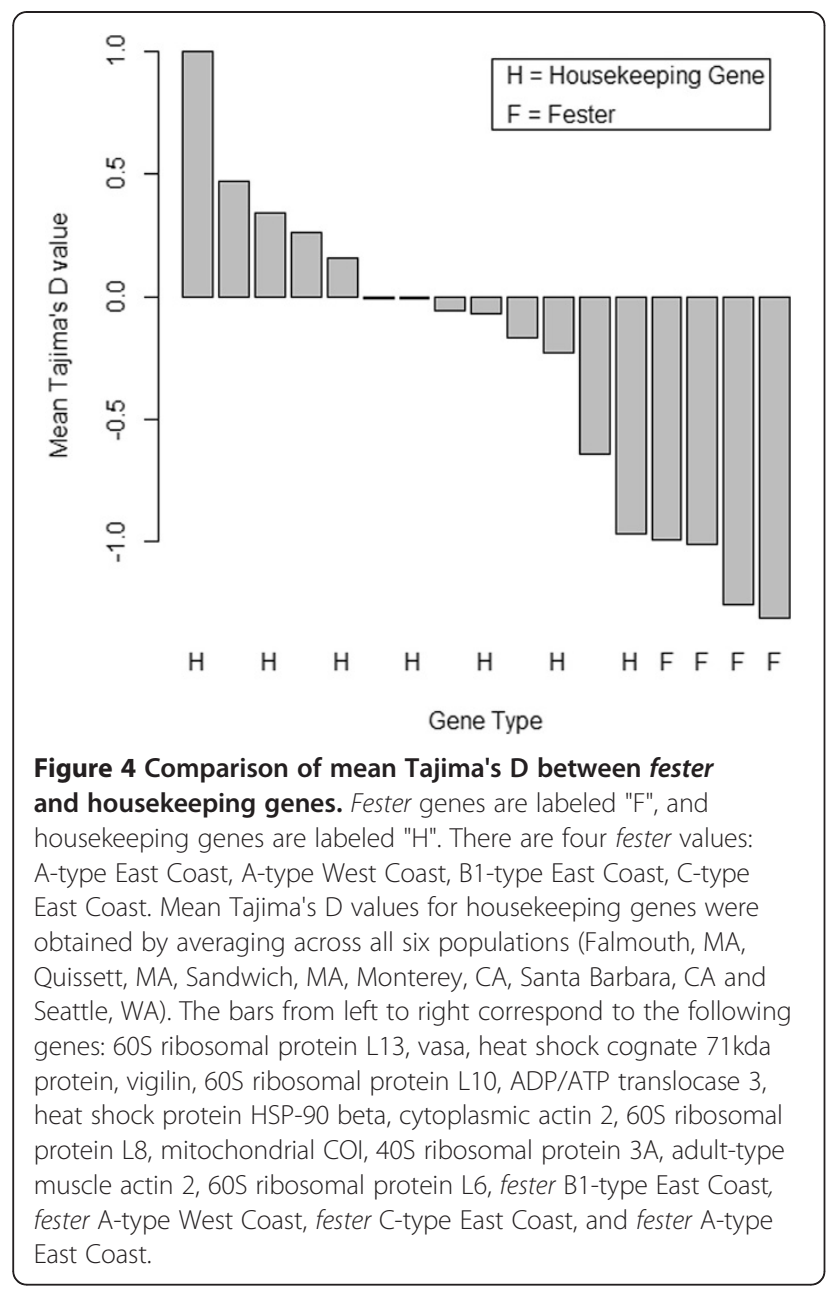

housekeeping gene values are non-overlapping. Specifically, all of the fester values for each statistic are lower than all of the housekeeping gene values. This clearly shows that fester does not experience the same evolutionary forces as the rest of the genome.

\section{Tests of selection: $\omega$ statistics}

The locations and number of all codons with $>95 \%$ posterior probability of directional/balancing selection are shown in Figure 7. Exons 1-7 are predicted to correspond to extracellular domains of the fester protein, Exons 8-10 to transmembrane domains. Codons with $<95 \%$ posterior probability of selection are not considered to be under directional/balancing selection. The majority of codons in the fester proteins have $\omega$ values $<1$, consistent with purifying selection.

A-type alleles East Coast. 27 codons have $>95 \%$ posterior probability of directional/balancing selection $(\omega>1)$. Exons 3, 4 and 8 have significantly higher $\omega$ values than the rest of the gene (Exon 3: $\mathrm{W}$ value $=5,616, \mathrm{p}$ value $=$ 0.020 , Exon 4: $\mathrm{W}$ value $=8,037, \mathrm{p}$ value $=0.007$, Exon 8:

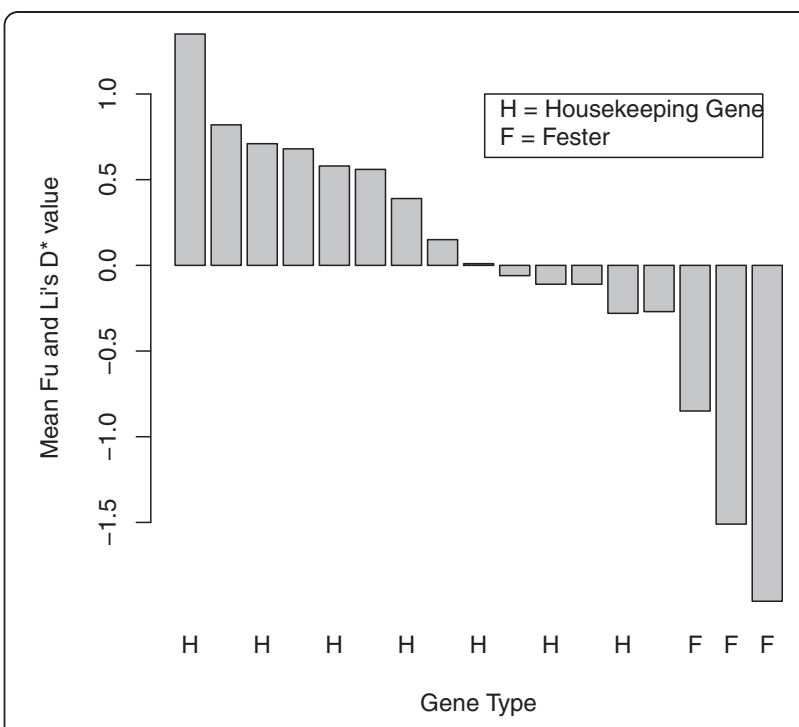

Figure 5 Comparison of mean Fu and Li's D* between fester and housekeeping genes. Fester genes are labeled "F", and housekeeping genes are labeled "H". There are four fester values: A-type East Coast, A-type West Coast, B1-type East Coast, C-type East Coast. Mean Fu and Li's $D^{*}$ values for housekeeping genes were obtained by averaging across all six populations (Falmouth, MA, Quissett, MA, Sandwich, MA, Monterey, CA, Santa Barbara, CA and Seattle, WA). The bars from left to right correspond to the following genes: vasa, 605 ribosomal protein L13, vigilin, heat shock cognate $71 \mathrm{kda}$ protein, heat shock protein HSP-90 beta, mitochondrial COI, ADP/ATP translocase 3, cytoplasmic actin 2, $40 \mathrm{~S}$ ribosomal protein $3 \mathrm{~A}$, adult-type muscle actin $2,60 \mathrm{~S}$ ribosomal protein $\mathrm{L} 6,60 \mathrm{~S}$ ribosomal protein L10, 605 ribosomal protein L8, fester B1-type East Coast, fester A-type West Coast, fester C-type East Coast, and fester A-type East Coast.

$\mathrm{W}$ value $=6,981, \mathrm{p}$ value $=0.013) . \underline{\text { A-type alleles West }}$ Coast. 19 codons have $>95 \%$ posterior probability of directional/balancing selection $(\omega>1)$. Exons 4,5 and 8 have significantly higher $\omega$ values than the rest of the gene $($ Exon 4: $\mathrm{W}$ value $=7,983, \mathrm{p}$ value $=0.0084$, Exon $5: \mathrm{W}$ value $=9,651, \mathrm{p}$ value $=0.0105$, Exon $8: \mathrm{W}$ value $=$ $7,478, \mathrm{p}$ value $=0.0007)$. B1-type alleles East Coast. 17 codons have $>95 \%$ posterior probability of directional/ balancing selection $(\omega>1)$. Exons 4,5 and 8 have significantly higher $\omega$ values than the rest of the gene (Exon $4: \mathrm{W}$ value $=8,032, \mathrm{p}$ value -0.014 , Exon $5: \mathrm{W}$ value $=$ $11,062, \mathrm{p}$ value $=<0.001$, Exon $8: \mathrm{W}$ value $=7,230$, $\mathrm{p}$ value $=0.0138)$. Exons $9-11$ do not have significantly higher $\omega$ values than the rest of the gene. C-type alleles East Coast. 15 codons have $>95 \%$ posterior probability of directional/balancing selection $(\omega>1)$. Exons 4,5 and 8 have significantly higher $\omega$ values than the rest of the gene (Exon 4: $\mathrm{W}$ value $=8,032$, $\mathrm{p}$ value -0.014 , Exon 5: $\mathrm{W}$ value $=11,062, \mathrm{p}$ value $=<0.001$, Exon $8: \mathrm{W}$ value $=$ 7,230 , p value $=0.0138$ ). Exons 9-11 do not have significantly higher $\omega$ values than the rest of the gene. 


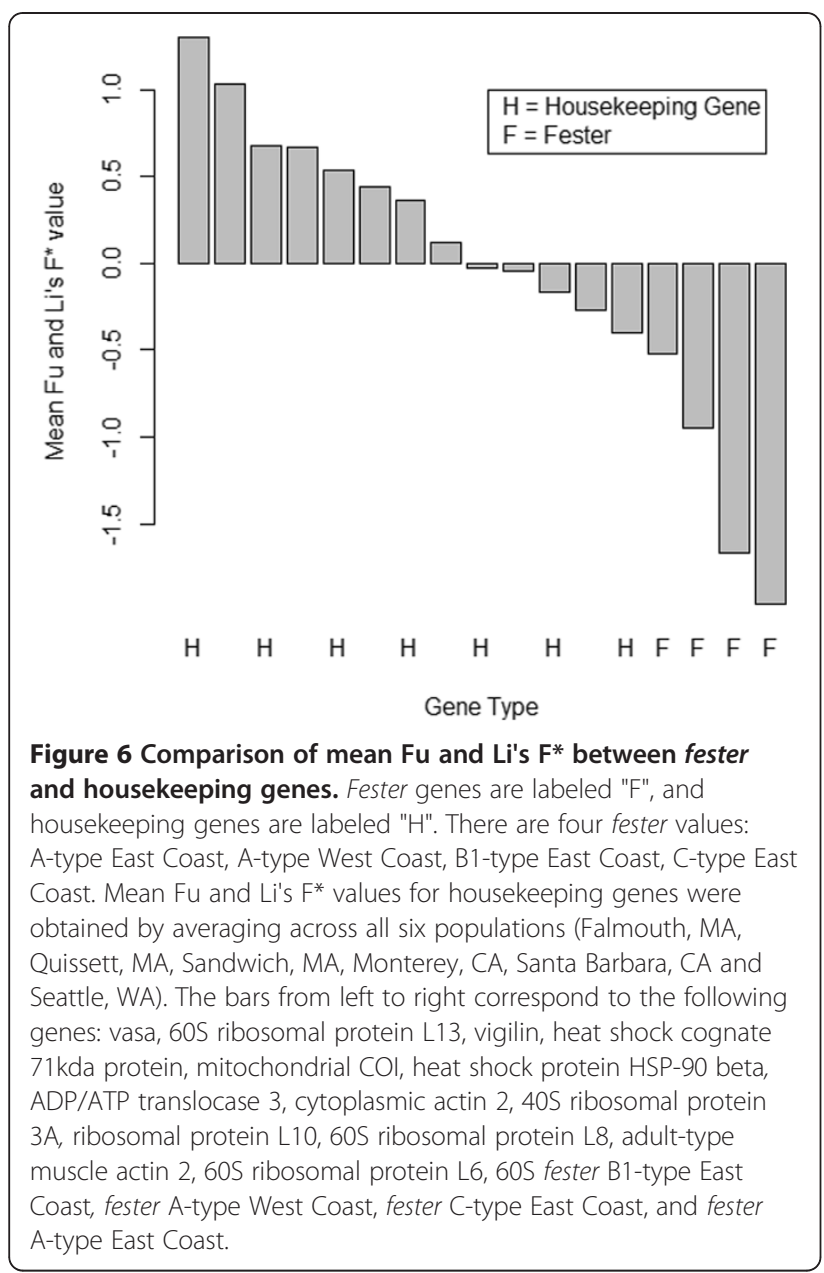

\section{Discussion}

\section{Tests of selection}

\section{Selection is occurring at the fester locus}

Two sets of hypotheses have generally been advanced for the maintenance of polymorphism at allorecognition loci - those invoking neutral processes, and those invoking selective processes (reviewed in [31]). All three analytical methods we employed (distribution of variation within and among populations, polymorphism statistics and $\omega$ statistics) provide evidence that selection is occurring at the fester locus.

Nearly all of the variation in the fester locus resides within populations, just as with FuHC [32]. The housekeeping genes have substantially more structure among populations within groups and among groups than fester (Figure 3). In addition, a majority of the pairwise $F_{s t}$ values are significant for the housekeeping genes, but only one is significant in fester A-type, and none in B1type or C-type. The East Coast exhibits more differentiation between populations than the West Coast: 15 intra-East Coast population pairs show differentiation whereas 19 intra-West Coast population pairs do

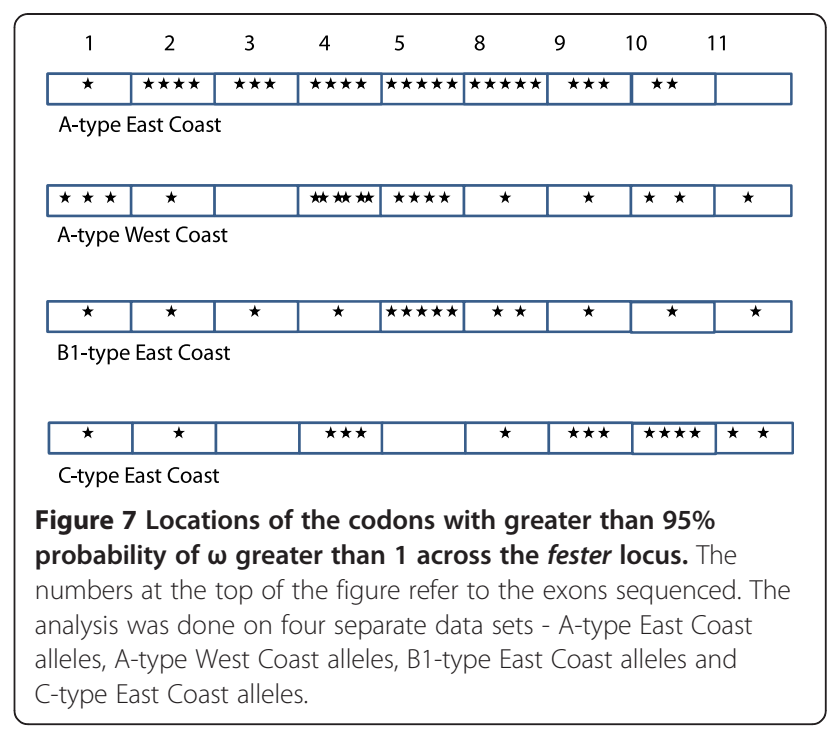

(Additional file 2). This variation in amount of differentiation may be due to the wider geographical sampling on the West Coast. However, any bias in AMOVA results due to higher differentiation on the West Coast than on the East Coast would affect both fester and housekeeping genes.

The population differentiation at the housekeeping loci confirms the significant genetic structure seen for neutral markers (microsatellites) in B. schlosseri [33,34]. These results are in sharp contrast to the lack of significant population differentiation at fester and FuHC.

The pattern seen here is consistent with balancing selection acting on fester. Loci experiencing balancing selection (which maintains variation) should have larger amounts of polymorphism within populations and smaller amounts among populations than neutral loci (assuming selection pressures are similar between populations), whereas the opposite pattern is expected for loci experiencing directional selection [27].

All polymorphism statistics (Tajima's D, Fu and Li's D* and $\mathrm{F}^{*}$ ) are significantly negative for the East Coast A-type alleles, and $\mathrm{Fu}$ and Li's $\mathrm{F}^{*}$ statistic is significantly negative for the West Coast A-type alleles, consistent with either purifying selection or a recent selective sweep at this haplotype (directional selection). These results are likely due to selection rather than demography, given that 10 of the housekeeping loci have no populations that were significant for any of the polymorphism statistics. The remaining three loci only have 1-2 populations (out of six) that were significant for one or more of the statistics. In addition, the housekeeping loci do not show a consistent negative trend of polymorphism statistics across all populations, as fester does. Figures 4, 5, 6 provide additional conformation that values of polymorphism statistics are more negative for fester than for housekeeping genes. 
Polymorphism statistics for B1-type and C-type alleles are always negative, but are not statistically different from zero. We cannot therefore reject the null hypothesis that the B1-type and C-type alleles are evolving neutrally, based on these statistics. However, fester B1-type and C-type are clearly on a different evolutionary trajectory than the rest of the B. schlosseri genome (Figures 4, $5,6)$ and $\omega$ statistics provide evidence for selection on all 3 of the fester-allele types tested: A, B1 and C.

Exons 4,5 and 8 have statistically higher $\omega$ values than the rest of the gene for the A-type West Coast group, the B1-type group, and the C-type group. The A-type East Coast group also highlights Exon 3 as significant, but not Exon 5. No putative conserved domains were detected when Exons 3 and 4 were submitted as queries to the NCBI non-redundant protein sequences database using BLASTp. Exon 5 encodes a short consensus repeat (SCR, or sushi) domain often found in vertebrate complement receptors (part of the innate immune system) [22]. Exon 8 is a functional transmembrane domain that was co-localized with CD45 to the cellular membrane [22]. Splice variants missing Exons 3 and 5 are occasionally found, but Exons 4 and 8 are present in all variants sequenced thus far [22]. We will focus on these 4 exons in further studies of fester's role in the allorecognition reaction, especially its interactions with FuHC.

Another gene encoded in the FuHC locus, uncle fester, represents a partial duplication of the fester locus, with the genomic region encoding Exons 4-9 nearly identical to fester's Exons 6-11, but uncle fester's Exons 1-3 do not appear to be related to any fester sequence [35]. This protein plays a role in initiating the rejection response between incompatible individuals, but is not involved in the fusion response [35]. Uncle fester, like fester, likely acts a receptor to the FuHC ligand. Two of the fester exons that have statistically higher $\omega$ values than the rest of the fester gene (Exons 4 and 5) are not related to the uncle fester sequence. Fester's Exon 8 is very similar to uncle fester's Exon 6, and has higher $\omega$ values than the rest of the fester gene.

\section{Type of selection occurring at the fester locus}

These data do not provide unambiguous support for a specific type of selection. The polymorphism statistics are consistent with either purifying selection or directional selection. The $\omega$ statistics show that the majority of the protein is experiencing purifying selection $(\omega<1)$, but that 15-27 codons are undergoing selection. The selection detected by $\omega$ statistics could be either balancing or directional; $\omega>1$ is compatible with either scenario. The distribution of variation within and among populations points towards balancing selection and away from directional selection.
The genetic basis of allorecognition has only been characterized in B. schlosseri, although the majority of botryllid species exhibit allorecognition. Identification and amplification of fester in other botryllids could allow us to discriminate between balancing and directional selection. First, we could determine if trans-species polymorphism is occurring. In several classic allorecognition systems, alleles from Species A are more closely related to alleles in Species B than they are to other alleles in Species A (e.g. SI loci SRK and SCR in several Arabidopsis species: [36,37], Het-c in Neurospora crassa: [38]). Such a pattern could be explained if alleles that pre-date speciation events have been maintained by balancing selection until the present time [39]. Second, divergence data would allow us to conduct several additional tests of selection (e.g. the HKA and McDonald-Kreitman tests) and apply other polymorphism statistics (e.g. Fu and Li's D and F).

Why might fester be evolving non-neutrally? If balancing selection is acting to maintain the allelic diversity at fester, what would be the mechanism of this selection? Given fester's likely function as a receptor of the ligand FuHC, fester may be evolving in response to $\mathrm{FuHC}$ evolution. Fusion can incur a significant fitness cost [40-42]; individuals with rare FuHC alleles will not fuse as often and may have higher fitness (negative frequency dependent selection). Fester alleles may evolve to bind with these rare FuHC alleles, and would therefore be subject to similar selective pressures as the FuHC alleles.

A recent study on the alr 2 allorecognition gene in Hydractinia comes to a similar conclusion [43]. They assert that alr 2 polymorphism is maintained by balancing selection, with negative frequency dependent selection as the mechanism. Hydractinia colonies also undergo fusion, and fusion can be costly for the losing genotype in situations where the two genotypes do not contribute equally to the next generation [43].

But if directional (rather than balancing) selection is maintaining variation at fester, what would be the biological explanation for this pattern? Fusion may also be beneficial to colonial ascidians such as B. schlosseri $[41,44]$. High rates of fusion are seen in the field (Botrylloides violaceus) [45] and the laboratory between unrelated individuals (Diplosoma listerianum) [46], and half-siblings (B. schlosseri) [47]. B. schlosseri juveniles also prefer to settle near related individuals $[48,49]$. In a scenario where fusion is beneficial, individuals with common fester alleles (and therefore higher fusion rates) would have higher fitness, and these common alleles would go to fixation.

\section{Relationships among fester haplotypes}

Because B1 is paraphyletic with respect to B2, the B2 copy may be derived from a duplication of the B1 copy. 
In our laboratory-reared strains in which the fester copies have been physically mapped, both $\mathrm{B} 1$ and $\mathrm{B} 2$ reside on a single haplotype, while the A haplotype has a single copy [22]. This is consistent with a duplication event creating the second B copy. Duplication events often drive genomic diversity in vertebrate $\mathrm{MHC}$ receptors including Ly49 genes in murines [50], NKG2 genes in humans [51], and lemurs [52], KIRs in humans [53,54], and heavy chain variable segment $\left(\mathrm{V}_{\mathrm{H}}\right)$ genes in humans [55]. However, more B2 alleles need to be sequenced before hypotheses about the origins of the B2 copy can be tested.

The A clade is equally divergent from both the B1/B2 and $\mathrm{C}$ clades, which are less divergent from each other than either is from the A clade. This pattern is consistent with at least 2 evolutionary scenarios: 1) the A haplotype experienced a duplication event which gave rise to the ancestor of the $\mathrm{B} 1 / \mathrm{B} 2$ and $\mathrm{C}$ haplotypes, or 2) a duplication at either $\mathrm{B} 1$ or $\mathrm{B} 2$ that gave rise to the $\mathrm{C}$ haplotype (or vice versa). Either way, A-type alleles are nearly evenly distributed between East Coast and West Coast populations (27 vs. 24), whereas B1-type and Ctype alleles are mostly found in East Coast populations (B1: 11/13, C: 17/21). This pattern suggests that the Atype alleles are more widespread in B. schlosseri source populations than either the B1-type or C-type alleles (both East and West Coast populations are invasive). The A-type alleles may therefore occupy the basal position in the fester phylogeny. But until we can sequence the fester locus from other Botryllus species, this remains speculation.

\section{Comparison of variation among fester allele types}

The A-type alleles are more variable than either the B1type or C-type alleles. While more A-type alleles (51) were sequenced than B1-type (13) or C-type (21) locus alleles, it is unlikely that sampling bias completely explains this pattern. We found 4 distinct A-type alleles and no such diversity was discovered in the B1, B2 or Ctype alleles. There are 3 possible explanations for this pattern: 1) stronger directional or balancing selection on the A haplotype, 2) the A haplotype is older than the other haplotypes and has accumulated more diversity through neutral or selective processes and/or 3) the lack of variation in the B1/B2 haplotype may be due to homogenization of variation due to unequal crossover or gene conversion between B1 and B2 (concerted evolution) [56]. The first hypothesis is supported by the results of the polymorphism statistics, which are consistent with the action of selection on the A-type alleles but not on the B1-type or C-type alleles. We cannot evaluate the second hypothesis without sequences from other botryllid species or more B. schlosseri populations. Regarding the third hypothesis, concerted evolution has long been thought to play a role in the evolution of immunoglobulin genes $[57,58]$. For example, this process has been suggested as a mechanism for the lack of variation in certain NKG2 genes in murines and humans [59]. But concerted evolution cannot necessarily explain lower levels of variation at the fester $\mathrm{C}$ haplotype compared to the fester A haplotype, and the importance of concerted evolution by inter-locus gene conversion for the evolution of $\mathrm{MHC}$ and immunoglobulin genes has been challenged by the more recent birth-and-death model [55].

Almost all measures of A-type allele diversity are higher in the East Coast group than the West Coast group. Although we sampled a larger number of East Coast than West Coast colonies with A-type alleles (22 vs. 18), the distinct evolutionary histories of these two sets of populations may also play a role in the diversity disparity. East Coast B. schlosseri Lineage A came from the Mediterranean Sea, which is the center of diversity for this group of lineages collectively known as B. schlosseri [60]. West Coast B. schlosseri Lineage A, on the other hand, came from the Western Pacific Ocean [60]. The Western Pacific Ocean populations came originally from the Mediterrean Sea [60]. East Coast B. schlosseri may be more diverse than West Coast $B$. schlosseri because native populations seeded the East Coast and nonnative populations seeded the West Coast.

\section{Conclusion}

Despite the prevalence and importance of allorecognition systems, the genetic basis of allorecognition has rarely been characterized outside the well-known MHC in vertebrates and SI in plants. Where loci have been identified, their evolutionary history is an open question. We have identified that the fester locus, a putative receptor in the B. schlosseri allorecognition system, evolves via natural selection. Studies such as these will increase our understanding of a widespread biological phenomenon.

\section{Methods \\ Sampling}

The species $B$. schlosseri comprises five divergent lineages (A-E) $[45,61]$. Lineage $A$ is thought to be native to the Mediterranean; it has spread throughout the Atlantic, Mediterranean, and Pacific Oceans through anthropogenic means. All of the B. schlosseri individuals in this study are Lineage A; populations from the West Coast of the U.S. originated from invasive western Pacific individuals, whereas populations from the East Coast of the U.S. originated from invasive Mediterranean individuals [60].

Colonies were collected from floating docks in each of 6 populations in 2009 and 2010: Falmouth, MA, Quissett, MA, Sandwich, MA, Monterey, CA, Santa Barbara, CA 
and Seattle, WA. Falmouth, MA and Quissett, MA are 3 miles apart, on Vineyard Sound and Buzzards Bay, respectively. Sandwich, MA is 25 miles from the Falmouth/Quissett area, on Cape Cod Bay. Santa Barbara, CA is 237 miles south of Monterey, CA and 1,113 miles south of Seattle, WA. Single systems were dissected from colonies and flash-frozen with liquid nitrogen and stored at $-80^{\circ} \mathrm{C}$.

\section{Amplification and sequencing Fester}

Total RNA was extracted from frozen tissue using the NucleoSpin Nucleic Acid and Protein Purification Kit (Macherey-Nagel). This RNA was used to synthesize single-stranded cDNA using SuperScript III reverse transcriptase (Invitrogen) and an oligo (dT) primer. 5-fold dilutions of the single-stranded cDNA was then PCRamplified with TRsa and TS-PCR primers. The resulting PCR product was diluted 50-fold and used as the template for PCR amplification. We used the following primer pair to amplify fester: Forward: 5' AAAGATAGTGCATCTGTTTCCATCCAA 3' and Reverse: 5' GCAGCTGCTTCGATTTTCTTTCCTTGT 3'. This primer pair amplified all fester haplotypes, and all exons were amplified in the initial PCR. Cycling conditions were $39 \mathrm{x}$ ( $95 \mathrm{C}$ for $30 \mathrm{sec}, 55 \mathrm{C}$ for $30 \mathrm{sec}, 72 \mathrm{C}$ for $1 \mathrm{~min}$ $30 \mathrm{sec}), 72 \mathrm{C}$ for $5 \mathrm{~min}$. PCR amplification was performed in a $20-\mu$ l total reaction volume with $13.6 \mu \mathrm{l}$ of H20, 4 $\mu$ l of 5x HF Buffer (Finnzymes), $0.2 \mathrm{mM}$ dNTPs, $0.6 \mu \mathrm{l}$ of $100 \%$ DMSO, $0.3333 \mu \mathrm{M}$ of each primer, $0.02 \mathrm{U} / \mu \mathrm{l}$ of Phusion Polymerase (Finnzymes) and $2 \mu \mathrm{l}$ of template DNA. PCR products were cloned using the $\mathrm{pGEM}^{\circledR}-\mathrm{T}$ kit and at least 12 clones per colony were sequenced in order to find alleles from all allele types: many colonies have more than 1 allele type. When an $\mathrm{A} / \mathrm{A}, \mathrm{B} 1 / \mathrm{B} 2 / \mathrm{B} 1 / \mathrm{B} 2$ or $\mathrm{C} / \mathrm{C}$ homozygote was found, we religated and transformed the original PCR product and sequenced additional clones to ensure that the colony was indeed a homozygote. Colony PCR products were incubated with $0.25 \mu$ l each of Exonuclease I and Shrimp Antarctic Phosphatase at $37^{\circ} \mathrm{C}$ for $30 \mathrm{~min}$, followed by $90^{\circ} \mathrm{C}$ for $10 \mathrm{~min}$ prior to sequencing.

Purified PCR products were sequenced with a Big Dye Terminator Cycle sequencing kit and a 96 capillary 3730xl DNA Analyzer (Applied Biosystems) at the UC Berkeley Sequencing Facility. A non-redundant set of alleles has been submitted to GenBank (Accession Numbers JN083148-JN083236). Sequences were edited, trimmed and aligned with Aligner (CodonCode Corporation, Dedham, MA). Colonies sequenced for each population are shown in Table 3. Only Exons 1-5 and $8-11$ were included in the alignment. We know that the PCR primers always amplified all 11 exons because the product was always $1.1 \mathrm{~kb}$. However, the full-length
cDNA was rarely incorporated into the bacterial vector; the longest amplicons recovered from the cloning process were almost always missing Exons 6 and/or 7 despite screening up to 192 clones per colony. Both Exons 6 and 7 were monomorphic when present, so we decided to exclude them from the alignment. No other splice variants were included in the alignment (i.e. all included sequences had Exons 1-5 and 8-11).

\section{Housekeeping genes}

We amplified 13 housekeeping genes (12 nuclear genes and mitochondrial cytochrome oxidase I) to determine whether the pattern of population structure and the values of polymorphism statistics were specific to the fester locus. Significant negative polymorphism statistics could be due to selective or demographic processes (e.g. recent population growth). But demographic processes would affect all genes, not just those involved in allorecognition. mtCOI is a gene commonly used for population structure analyses in B. schlosseri (e.g. $[34,60,61])$. Two of the 12 nuclear loci were found in GenBank (adult-type muscle actin 2, Accession \#FN178504.1 and vasa, Accession \#FJ890989.1) and the other 10 were located in our B. schlosseri EST database (40S ribosomal protein 3A, 60S ribosomal protein L6, 60S ribosomal protein L8, 60S ribosomal protein L10, 60S ribosomal protein L13, heat shock cognate $71 \mathrm{kda}$ protein, cytoplasmic actin 2, ADP/ATP translocase 3, heat shock protein HSP-90 beta, and vigilin).

Template for PCR amplification was generated as described above for the fester locus. Primers and thermocycling conditions for each gene are available from the authors. vasa PCR products were cloned as described for the fester locus. The PCR products of the other nuclear loci were sequenced directly. PCR products were incubated with $0.25 \mu \mathrm{l}$ each of Exonuclease I and Shrimp Antarctic Phosphatase at $37^{\circ} \mathrm{C}$ for $30 \mathrm{~min}$, followed by $90^{\circ} \mathrm{C}$ for $10 \mathrm{~min}$.

Purified PCR products were sequenced with a Big Dye Terminator Cycle sequencing kit and a 96 capillary 3730xl DNA Analyzer (Applied Biosystems) at the UC Berkeley Sequencing Facility. Sequences that were obtained by direct sequencing of PCR products (all nuclear sequences minus vasa) were phased in DnaSP 5.10.01 [62]. All sequences have been submitted to GenBank (40S ribosomal protein 3A: JQ596880-JQ596936, 60S ribosomal protein L6: JQ596937-JQ597084, $60 \mathrm{~S}$ ribosomal protein L8: JQ597085-JQ597174, 60S ribosomal protein L10: JQ597175-JQ597294, 60S ribosomal protein L13: JQ597595-JQ597716, heat shock cognate 71kda protein: JQ597295-JQ597430, cytoplasmic actin 2: JQ597431-JQ597548, ADP/ATP translocase 3: JQ597549JQ597594, heat shock protein HSP-90 beta: JQ597717JQ597826, adult-type muscle actin 2: JQ597827-JQ597974, 
Table 3 Fester genotypes of sequenced colonies

\begin{tabular}{|c|c|c|c|c|c|c|c|}
\hline Populations & Number of Colonies & $A / A$ & A/B1/B2 & B1/B2/B1/B2 & $A / C$ & $\mathrm{C} / \mathrm{C}$ & $\mathrm{A} / \mathrm{B} 1 / \mathrm{B} 2 / \mathrm{C}$ \\
\hline Falmouth, MA & 12 & 2 & 2 & 4 & 1 & 3 & 0 \\
\hline Monterey, CA & 4 & 1 & 0 & 2 & 0 & 1 & 0 \\
\hline Quissett, MA & 13 & 7 & 2 & 2 & 1 & 1 & 0 \\
\hline Sandwich, MA & 10 & 1 & 0 & 1 & 5 & 2 & 1 \\
\hline Santa Barbara, CA & 8 & 6 & 1 & 0 & 0 & 1 & 0 \\
\hline Seattle, WA & 12 & 8 & 1 & 1 & 1 & 1 & 0 \\
\hline
\end{tabular}

mtCOI: JN083237-JN083303, vasa: JN083304-JN083376, vigilin: JQ597975-JQ598070). Sequences were edited, trimmed and aligned with Aligner (CodonCode Corporation, Dedham, MA).

\section{Relationships among fester haplotypes}

We used RAxML 7.2.7 on the CIPRES web portal to obtain the best-scoring ML tree, as well as bootstrap support for each node on this tree [63]. We used the GTR $+\mathrm{G}$ likelihood model of nucleotide substitution as implemented in RAxML. All nodes with less than 50\% support were collapsed, and the resulting tree was visualized using FigTree 1.3.1 [64].

Bayesian analyses were performed with MrBayes 3.1.2 [65]. The GTR+G model of nucleotide substitution was applied $($ Nset $=6)$. Each analysis was run for 10 million generations, with sampling every 1000 generations. The first 2000 trees were eliminated as burn-in. The runs were completed using the Computational Biology Service Unit at Cornell University which is partially funded by the Microsoft Corporation.

\section{Comparison of variation among fester allele types}

The average number of nucleotide substitutions per site $\left(D_{x y}\right)$ and the number of net nucleotide substitutions per site $\left(D_{a}\right)$ between each pair of allele types was calculated in DnaSP 5.10.01 [62]. $\mathrm{D}_{\mathrm{a}}$ corrects for within-allele-type variation [66]. The three allele types analyzed are A-type, B1-type, and C-type. For all population-level analyses, we analyze each allele type separately because each has a separate evolutionary history, and because including divergent alleles in the same data set could create artifacts. When analyzing population level data, we use the term "allele type" instead of "haplotype". B2 alleles were recovered from an insufficient number of colonies to be included in population level analyses, so our analyses were done on B1-type alleles rather than on the B1/B2 haplotype.

\section{Recombination}

Intragenic recombination was determined in the East Coast and West Coast groups for the fester A-type alleles, and for the East Coast group in the fester B1-type and C-type alleles. Recombination was assessed by calculating $R_{m}$, the minimum number of recombination events in DnaSP 5.10.01 [62] and the correlation between physical distance and 3 measures of linkage disequilibrium (LD): $\mathrm{r}^{2}, \mathrm{D}^{\prime}$ and $\mathrm{G} 4$ in program permute [67].

\section{Selection inference: Distribution of polymorphism within and among populations}

We characterized population structure within B. schlosseri for fester A-type, B1-type, and C-type alleles and all housekeeping genes using an analysis of molecular variance (AMOVA), fixation indices $\left(\mathrm{F}_{\mathrm{ct}}, \mathrm{F}_{\mathrm{sc}}\right.$ and $\left.\mathrm{F}_{\mathrm{st}}\right)$, and pairwise $F_{\text {st }}$ values between populations in Arlequin 3.5.1.2 [68]. The fester B2-type alleles were not analyzed, as only 2 alleles were recovered from all colonies sequenced. For the fester A-type alleles and all the housekeeping loci, 2 groups (East Coast and West Coast) were analyzed, with 3 populations in each group (East Coast: Falmouth, MA, Quisset, MA and Sandwich, MA. West Coast: Monterey, CA, Santa Barbara, CA, Seattle, WA). Molecular variance was therefore partitioned 3 ways: among groups, among populations within groups, and within populations. For the B1-type and Ctype alleles, only 1 group (East Coast) was analyzed, as few West Coast colonies had B1-type or C-type alleles. Molecular variance was therefore assigned among and within populations only.

\section{Tests of selection: polymorphism statistics}

For East Coast and West Coast alleles separately (fester A-type alleles), East Coast alleles (fester B1-type and Ctype alleles), and each of the six populations (housekeeping genes), we calculated the summary statistics $\theta, \pi$, number of haplotypes, and haplotype diversity in DnaSP 5.10.01 [62]. We also employed Tajima's D [28] and Fu and Li's D* and $F^{*}[29]$ test statistics. Statistical significance of $\mathrm{D}, \mathrm{D}^{*}$, and $\mathrm{F}^{*}$ were determined using $10,000 \mathrm{co}-$ alescent simulations in DnaSP. We performed 2 sets of coalescent simulations: based on $\theta$ and segregating sites. Estimates of per gene recombination (R) for each population were made in DnaSP and were then imported into the simulations. Tajima's D, Fu and Li's D* and F* statistics were calculated for fester A-type alleles (East Coast and West Coast groups), B1-type alleles (East Coast 
group only), C-type alleles (East Coast group only), and all housekeeping genes (all six populations).

\section{Tests of selection: $\omega$ statistics}

Omega values $\left(\omega=\mathrm{d}_{\mathrm{N}} / \mathrm{d}_{\mathrm{S}}\right)$ and associated 95\% HPD (highest posterior density) regions across fester A-type, B1-type and C-type alleles were estimated using the program omegaMap 0.5 [67]. omegaMap calculates $\omega$ values in the presence of intragenic recombination [67]. omegaMap runs were carried out using the resources of the Computational Biology Service Unit at Cornell University which is partially funded by the Microsoft Corporation. We chose 250,000 iterations for each run, with thinning set to 1,000 . We used an improper inverse distribution for $\mu$, and $\kappa$, and an inverse distribution for $\omega$ and $\rho$. Initial parameter values for $\mu$ and $\kappa$ were 0.1 , and 3.0, respectively. $\omega$ and $\rho$ priors were set between 0.01 and 100. An independent model was used for $\omega$, so that $\omega$ values were allowed to vary across sites. The number of iterations discarded as burnin varied across runs, but was determined by plotting the traces of $\mu$ and $\kappa$; iterations affected by the starting value of the parameter were discarded. 2 independent runs were conducted for each population. These 2 runs were combined in all cases, after it was determined that the mean and $95 \%$ highest posterior density (HPD) regions for each parameter in the 2 runs matched closely.

We also calculated the posterior probability of selection per codon across the protein. Exons that contained clusters $(\geq 2)$ of these codons were identified; MannWhitney $\mathrm{U}$ tests in $\mathrm{R}$ 2.12.2 were performed on these exons to determine if they had higher $\omega$ values than the rest of the protein.

\section{Additional files}

Additional file 1: Best scoring Maximum Likelihood Tree of fester A,

B1, B2 and C allele types. Blue $=$ A-type alleles, Orange $=$ B1-type alleles, Purple $=$ B2-type alleles, Black $=$ C-type alleles. FLM $=$ Falmouth $M A, M R=$ Monterey CA, QST = Quissett MA, SW = Sandwich MA,

$\mathrm{SB}=$ Santa Barbara CA, SE = Seattle WA. Numbers are bootstrap values from 1,000 replicates.

Additional file 2: AMOVA, Fixation Indices and Pairwise Fst values for fester and all housekeeping genes.

Additional file 3: Tajima's D, Fu and Li's $D^{*}$ and F* statistics for all Housekeeping Genes.

\section{Competing interests}

The authors declare that they have no competing interests.

\section{Authors' contributions}

MLN generated the data, performed the analyses and wrote the manuscript. AWD provided funding and edited the manuscript. Both authors have read and approved the final manuscript.

\section{Authors' information}

MLN studies the evolution of allorecognition in B. schlosseri and the evolution of reproductive isolation and speciation in the solitary ascidian Ciona intestinalis. AWD studies the evolution and molecular mechanisms of allorecognition in B. schlosseri, as well as the mechanisms of germ line parasitism in B. schlosseri.

Data accessibility

All sequences have been submitted to GenBank.

\section{Acknowledgements}

We thank S. Rendulic for collecting many of the B. schlosseri colonies used in this study, and Nathan Derieg, Scott Hodges, Daisie Huang, Todd Oakley, Sabrina Pankey, Alison Pischedda, Steve Proulx, and Des Ramirez for comments on the manuscript. This work was supported by National Science Foundation Grant IOS-0842138 to AWD.

\section{Author details}

'Division of Science and Mathematics, Centre College, 600 W. Walnut Street, Danville, KY 40422, USA. ²Department of Molecular, Cellular, and

Developmental Biology, University of California, Santa Barbara, Santa Barbara, CA 93106, USA.

Received: 24 September 2012 Accepted: 19 December 2012 Published: 22 December 2012

\section{References}

1. Buss L: Somatic cell parasitism and the evolution of somatic tissue compatibility. Proc Natl Acad Sci USA 1982, 79:5337-5341.

2. Mercier A, Sun Z, Hamel JF: Internal brooding favours pre-metamorphic chimerism in a non-colonial cnidarian, the sea anemone Urticina felina. Proc Roy Soc Lond Ser B 2011, 278:3517-3522.

3. Allen AM, Hiscock SJ: Evolution and phylogeny of self-incompatibility systems in angiosperms. In Self-incompatibility in flowering plants evolution, diversity and mechanisms. 1st edition. Edited by Franklin-Tong VE. Heidelberg, Germany: Springer-Verlag; 2008:73-101.

4. Raftos D: Allorecognition and humoral immunity and tunicates. Ann New York Acad Sci 1994, 712:227-244.

5. Saito $Y$, Hirose $E$, Watanabe $H$ : Allorecognition in compound ascidians. Intl J Dev Biol 1994, 38:237-247.

6. Harada Y, Takagaki Y, Sunagawa M, Saito H, Yamada L, Taniguchi H, Shoguchi E, Sawada H: Mechanism of self sterility in a hermaphroditic chordate. Science 2008, 320:548-550.

7. Gibbs KA, Urbanowski ML, Greenberg EP: Genetic determinants of self identity and social recognition in bacteria. Science 2008, 321:256-259.

8. Hughes RN, Manriquez PH, Morley S, Craig SF, Bishop JDD: Kin or selfrecognition? Colonial fusibility of the bryozoan Celleporella hyalina. Evol Dev 2004, 6:431-437.

9. Shaulsky G, Kessin R: The cold war of the social amoebae. Curr Biol 2007, 17:684-692.

10. Hidaka M, Yurugi K, Sunagawa S, Kinzie RA III: Contact reactions between young colonies of the coral Pocillopora damicornis. Coral Reefs 1997, 16:13-20.

11. Glass NL, Jacobson DJ, Shiu PK: The genetics of hyphal fusion and vegetative incompatibility in filamentous ascomycete fungi. Ann Rev Gen 2000, 34:165-186.

12. Grosberg RK, Levitan DR, Cameron BB: Evolutionary genetics of allorecognition in the colonial hydroid Hydractinia symbiolongicarpus. Evolution 1996, 50:2221-2240.

13. Runions $\mathrm{CJ}$, Owens $\mathrm{JN}$ : Evidence of pre-zygotic self-incompatibility in a conifer. In Reproductive biology. Edited by Owens SJ, Rudall PJ. Kew, UK: Royal Botanic Gardens; 1998:255-264.

14. Pandey KK: Incompatibility in Abutilon 'Hybridum'. Am J Bot 1960, 47:877-883.

15. Clark J: Plasmodial incompatibility in the myxomycete Didymium squamulosum. Mycologia 2003, 95:24-26.

16. Santelices B, Correa JA, Aedo D, Flores V, Hormazabal M, Sanchez P. Convergent biological processes in coalescing Rhodophyta. J Phyc 1999, 35:1127-1149.

17. Fernandez-Busquets $X$, Burger MM: Cell adhesion and histocompatibility in sponges. Mic Res Tech 1999, 44:204-218.

18. Flajnik MF, Kasahara M: Origin and evolution of the adaptive immune system: genetic events and selective pressures. Nat Rev Gen 2010, 11:47-59. 
19. De Tomaso AW, Nyholm SV, Palmeri KJ, Ishizuka KJ, Ludington WB, Mitchel K, Weissman IL: Isolation and characterization of a protochordate histocompatibility locus. Nature 2005, 438:454-459.

20. Benabentos R, Hirose S, Sucgang R, Curk T, Katoh M, Ostrowski E, Strassmann J, Queller D, Zupan B, Shaulsky G, Kuspa A: Polymorphic members of the lag-gene family mediate kin-discrimination in Dictyostelium. Curr Biol 2009, 19:567-572.

21. Nicotra ML, Powell AE, Rosengarten RD, Moreno M, Grimwood J, Lakkis FG Dellaporta SL, Buss LW: A hypervariable invertebrate allodeterminant. Curr Biol 2009, 19:583-589.

22. Nyholm SV, Passegue E, Ludington WB, Voskoboynik A, Mitchel K, Weissman IL, De Tomaso AW: fester, a candidate allorecognition receptor from a primitive chordate. Immunity 2006, 25:163-173.

23. Bernatchez $L$, Landry C: MHC studies in nonmodel vertebrates: what have we learned about natural selection in 15 years? J Evol Biol 2003, 16:363-377.

24. Garrigan D, Hedrick PW: Detecting adaptive molecular polymorphism: lessons from the MHC. Evolution 2003, 57:1707-1722.

25. Nydam ML, De Tomaso AW: Creation and maintenance of variation in allorecognition loci: molecular analysis in various model systems. Front Mol Inn Immunol 2011, 2:1-6.

26. Yokoyama S, Nei M: Population dynamics of sex-determining alleles in honey bees and self-incompatibility alleles in plants. Genetics 1979, 91:609-626.

27. Schierup $M H$, Vekemans $X$, Charlesworth D: The effect of subdivision on variation at multi-allelic loci under balancing selection. Gen Res 2000, 76:51-62.

28. Tajima F: Statistical method for testing the neutral mutation hypothesis by DNA polymorphism. Genetics 1989, 123:585-595.

29. Fu YX, Li WH: Statistical tests of neutrality of mutations. Genetics 1993, 133:693-709.

30. Garrigan D, Hedrick PW: Detecting adaptive molecular polymorphism: lessons from the MHC. Evolution 2003, 57:1707-1722.

31. Grosberg RK: The evolution of allorecognition specificity in clonal invertebrates. Quart Rev Biol 1988, 63:377-412.

32. Nydam ML, Taylor AA, De Tomaso AW: Evidence for selection on a chordate histocompatibility locus. Evolution 2012, doi:10.1111/j.15585646.2012.01787.x

33. Ben-Shlomo R, Reem E, Douek J, Rinkevich B: Population genetics of the invasive ascidian Botryllus schlosseri from South American coasts. Mar Ecol Prog Ser 2010, 412:85-92.

34. Bock DG, Maclsaac HJ, Cristescu ME: Multilocus genetic analyses differentiate between widespread and spatially restricted cryptic species in a model ascidian. Proc Roy Soc Lond Ser B 2012, doi:10.1098/ rspb.2011.2610.

35. McKitrick TR, Muscat CC, Pierce JD, Bhattacharya D, De Tomaso AW Allorecognition in a basal chordate consists of independent activating and inhibitory pathways. Immunity 2011, 34:616-626.

36. Sato K, Nishio T, Kimura R, Kusaba M, Suzuki T, Hatakeyama K, Ockendon DJ, Satta Y: Coevolution of the S-Locus genes SRK, SLG, and SP11/SCR in Brassica oleracea and B. rapa. Genetics 2002, 162:931-940.

37. Guo YL, Zhao X, Lanz C, Weigel D: Evolution of the $S$-locus region in Arabidopsis thaliana relatives. Plant Phys 2011, 157:937-946.

38. Wu J, Saupe SJ, Glass NL: Evidence for balancing selection operating at the het-c heterokaryon incompatibility locus in a group of filamentous fungi. Proc Natl Acad Sci USA 1998, 95:12398-12403.

39. Takahata N: A simple genealogical structure of strongly balanced allelic lines and trans-species evolution of polymorphism. Proc Natl Acad SCi USA 1990, 87:2419-2423.

40. Rinkevich B, Weissman IL: Chimeras vs. genetically homogeneous individuals: potential fitness costs and benefits. Oikos 1992, 63:119-124.

41. Chadwick-Furman NE, Weissman IL: Life history plasticity in chimeras of the colonial ascidian Botryllus schlosseri. Proc Roy Soc London Ser B 1995, 262:157-162.

42. Chadwick-Furman NE, Weissman IL: The effects of allogeneic contact on life- history traits of the colonial ascidian Botryllus schlosseri in Monterey Bay. Biol Bull 2003, 205:133-143.

43. Gloria-Soria A, Moreno MA, Yund PO, Lakkis FG, Dellaporta SL, Buss LW: Evolutionary genetics of the hydroid allodeterminant alr2. Mol Biol Evol 2012, doi:10.1093/molbev/mss197.

44. Rinkevich B, Shapira M: Multi-partner urochordate chimeras outperform two-partner chimerical entities. Oikos 1999, 87:315-320.
45. Westerman E, Dijkstra J, Harris L: High natural fusion rates in a botryllid ascidian. Mar Biol 2009, 156:2613-2619.

46. Bishop JDD, Sommerfeldt AD: Not like Botryllus: indiscriminate postmetamorphic fusion in a compound ascidian. Proc Roy Soc Lond B 1999, 266:241-248.

47. Carpenter MA, Powell JH, Ishizuka KJ, Palmeri KJ, Rendulic Z, De Tomaso A: Growth and long-term somatic and germline chimerism following fusion of juvenile Botryllus schlosseri. Biological Bulletin 2011, 220:57-70.

48. Ben-Shlomo R, Motro U, Paz G, Rinkevich B: Pattern of settlement and natural chimerism in the colonial urochordate Botryllus schlosseri. Genetica 2008, 132:51-58.

49. Grosberg RK, Quinn JF: The genetic control and consequences of kin recognition by the larvae of a colonial marine invertebrate. Nature 1986, 322:456-459.

50. Hao L, Nei M: Rapid expansion of killer cell immunoglobulin-like receptor genes in primates and their coevolution with MHC Class I genes. Gene 2005, 347:149-159.

51. Glienke J, Sobanov Y, Brostjan C, Steffens C, Nguyen C, Lehrach H, Hofer E, Francis $F$ : The genomic organization of NKG2C, E, F and $D$ receptor genes in the human natural killer gene complex. Immunogen 1998, 48:163-173.

52. Averdam A, Petersen B, Rosner $C$, Neff J, Roos C, Eberle M, Aujard F, Munch C, Schempp W, Carrington M, Shiina T, Inoko H, Knaust F, Coggill P, Sehra $H$, Beck S, Abi-Rached L, Reinhardt R, Walter L: A novel system of polymorphic and diverse NK cell receptors in primates. PloS Genetics 2009, 5:e1000688.

53. Martin AM, Kulski JK, Gaudieri S, Witt CS, Freitas EM, Trowsdale J, Christiansen FT: Comparative genomic analysis, diversity and evolution of two KIR haplotypes A and B. Gene 2004, 335:121-131.

54. Norman P, Abi-Rached L, Gendzekhadze K, et al: Meiotic recombination generates rich diversity in NK cell receptor genes, alleles, and haplotypes. Genome Res 2009, 19:757-769.

55. Nei M, Gu X, Sitnikova T: Evolution by the birth-and-death process in multigene families of the vertebrate immune system. Proc Natl Acad Sci USA 1997, 94:7799-7806.

56. Liao D: Concerted Evolution: Molecular mechanism and biological implications. Am J Hum Gen 1999, 64:24-30.

57. Hood L, Campbell JH, Elgin SCR: The organization, expression, and evolution of antibody genes and other multigene families. Ann Rev Gen 1975, 9:305-353.

58. Ohta T: On the evolution of multigene families. Theor Pop Biol 1983, 23:216-240.

59. Vance RE, Jamieson AM, Raulet DH: Recognition of the Class lb molecule Qa-1 by putative activating receptors CD94/NKG2C and CD94/NKG2E on mouse natural killer cells. J. Exp. Med 1999, 190:1801-1812.

60. Lejeusne C, Bock DG, Therriault TW, Maclsaac HJ, Cristescu ME: Comparative phylogeography of two colonial ascidians reveals contrasting invasion histories in North America. Biol Inv 2011, 13:635-650.

61. Lopez-Legentil S, Turon X, Planes S: Genetic structure of the star sea squirt, Botryllus schlosseri introduced into southern European harbours. Mol Ecol 2006, 15:3957-3967.

62. Librado P, Rozas J: DnaSP v5: A software for comprehensive analysis of DNA polymorphism data. Bioinform 2009, 25:1451-1452.

63. Stamatakis A, Hoover $\mathrm{P}$, Rougemont J: A rapid bootstrap algorithm for the RaxML web servers. Syst Biol 2008, 57:758-771.

64. Rambaut A: FigTree 1.3.1. Computer program available from website http:// tree.bio.ed.ac.uk/software/figtree. 2006-2009.

65. Ronquist F, Huelsenbeck JP: MRBAYES 3: Bayesian phylogenetic inference under mixed models. Bioinform 2003, 19:1572-1574

66. Nei M: Molecular Evolutionary Genetics. New York: Columbia University Press; 1987.

67. Wilson DJ, McVean G: Estimating diversifying selection and functional constraint in the presence of recombination. Genetics 2006, 172:1411-1425.

68. Excoffier L, Lischer HEL: Arlequin suite ver 3.5: A new series of programs to perform population genetics analyses under Linux and Windows. Mol Ecol Res 2010, 10:564-567.

doi:10.1186/1471-2148-12-249

Cite this article as: Nydam and De Tomaso: The fester locus in Botryllus schlosseri experiences selection. BMC Evolutionary Biology 2012 12:249. 